\title{
THE USING OF WHATSAPP IN TEACHING PRONUNCIATION PRACTICE TO THE THIRD SEMESTER STUDENTS OF TADRIS ENGLISH STUDY PROGRAM IN IAIN PALU
}

\author{
Afifah \\ English Tadris Study Program, Faculty of Tarbiyah and Teacher Training \\ State Institute for Islamic Studies Palu \\ Email:eefaviva@gmail.com
}

\begin{abstract}
This research focuses on the using of WhatsApp in teaching pronunciation practice to the third semester students of Tadris English Study Program in IAIN Palu. The research question is "How is the using of WhatsApp in teaching Pronunciation Practice to the third semester students of Tadris English Study Program in IAIN Palu?" This is a qualitative research by using two instruments of data collections namely questionnaire and interview. The participants consisted of 19 third semester students of Tadris English Study Program of State Institute for Islamic Studies (IAIN) Palu. The researcher conducted five meetings of Pronunciation Practice class to the participants via WhatsApp before distributing the questionnaire and interview sheet. The questionnaire consisted of five questions by applying Likert Scale, while the interview consisted of ten questions. From the questionnaire and interview, the researcher concludes that the using of WhatsApp in teaching Pronunciation Practice to the third semester students of Tadris English Study Program in IAIN Palu is practical. The students could understand the material shared via WhatsApp in the form of documents shared, videos shared, as well as voice recording shared. They could use the features in WhatsApp well such as sharing documents, voice notes, sharing videos, video call and so on in learning pronunciation practice. The students like Pronunciation Practice Class and enjoy studying it via WhatsApp. Learning Pronunciation Practice via WhatsApp has some advantages such as time flexibility as well as structured and easily accessed materials. However, it also has some limitations such as internet data availability and video call limitation. Besides, the participants faced several obstacles in learning Pronunication Practice via WhatsApp, such as the limitation of smartphone memory to save files, down internet server, and unavailability of internet data. Nevertheless, they could passed those obstacles well by deleting some unused files to give more space to the memory and finding out wifi connection to stay connected to WhatsApp when the server was down or they ran out of internet data. They could understand the teaching of Pronunciation Practice via WhatsApp by downloading and reading the documents shared, the videos shared, and the voice recording shared by the lecturer. When they found a difficulty, they asked their friends or the lecturer via WhatsApp group.
\end{abstract}

Key words: WhatsApp, pronunciation practice 


\section{Introduction}

Pronunciation is one of the language components besides grammar and vocabulary. Having good grammar and sufficient vocabulary is not enough to make someone speak English well. Pronunciation contributes much in speaking skill as well as in listening skill. Having good pronunciation enables a speaker to easily tell his ideas to the listener(s). For the listener, listening to a speaker having fluent and understandable pronunciation will create a comfortable and joyful experience of conversation.

In Tadris English Study Program of IAIN Palu, Pronunciation Practice becomes one of the compulsory subjects to study in the third semester. It is divided into two parts - Pronunciation Practice 1 containing the material of pronouncing vowels and Pronunciation Practice 2 containing the material of pronouncing consonants. Pronunciation Practice 1 is taught to the second semester students, while Pronunciation Practice 2 is taught to the third semester students. In the normal situation, the teaching and learning is conducted by face to face classroom meeting. The lecturer explains the material in front of the classroom by being the model of pronunciation practice class. However, COVID-19 (Corona Virus Disease 2019) attacks Indonesia since January $2020^{1}$ and Central Sulawesi since March 2020 ${ }^{2}$. It directly gives impact to the system of education in Indonesia in which classroom teaching and learning is not allowed to be

${ }^{1}$ Tim detikcom, Kapan Sebenarnya Corona Pertama Kali Masuk RI? (detiknews: retrieved from news.detik.com, November 29 2020)

2 M. Qadri, Kasus Pertama, Satu Warga Sulteng Dikonfirmasi Positif Corona (detiknews: retrieved from news.detik.com November 29 2020) conducted in face to face meetings but replaced to online class.

The disallowance of face to face class implies to the teaching and learning in all levels of education in Indonesia. In order to suppress the contagion of COVID-19 in Indonesia, the Minister of Education has issued the decree of the Minister of Education, Number 03/KB/2020. ${ }^{3}$ The main points of the regulation has implication to the system of education as follows: (1) All the activities in schools and colleges/universities gathering a lot of people should be avoided including face to face class; (2) Face to face class is replaced to online class; (3) Students stay at home and study by using laptop or android. Following the regulation, the Rector of IAIN Palu has announced the policy of teaching and learning in IAIN Palu during COVID19. The leaflet numbered 760/In.13/HK.00.7/03/2020 was spread over to the society of academician of IAIN Palu including the lecturers and students in March 2020. ${ }^{4}$

Online classes have some advantages to students. By online learning, students do not have to spend money to reach campus just to attend a class. They also have freedom to explore their best way by using their own learning style to understand the

\footnotetext{
3 Keputusan Bersama Menteri Pendidikan dan Kebudayaan, Menteri Agama, Menteri Kesehatan, dan Menteri Dalam Negeri Republik Indonesia Nomor 03/KB/2020, Nomor 612 Tahun 2020, Nomor HK.01.08/Menkes/502/2020, Nomor 119/4536/SJ Tentang Panduan Penyelenggaraan Pembelajaran Pada Tahun Ajaran 2020/2021 dan Tahun Akademik 2020/2021 di Masa Pandemi Coronavirus Disease 2019 (COVID-19)

$\begin{array}{lcrr} & \text { ANTARANEWS, IAIN } & \text { Palu } & \text { Kuliah } \\ \text { Daring } & \text { Cegah } & \text { Penyebaran } & \text { COVID-19 } \\ \text { (ANTARANEWS: } & \text { retrieved } & \text { from } \\ \text { www.antaranews.com November } 282020) & \end{array}$
}


teaching materials. Attending online classes also enables students to be independent individuals who can increase their self confidence to interact with their classmates through online teaching media, set their goals of study, to set their time to meet the deadline of assignments, and to enhance their ability in using the best parts offered by technology. ${ }^{5}$

Utilizing applications in E-learning requires both lecturers and students to be technologically literate. Google Classroom, Moodle, Zoom Cloud Meetings, WhatsApp, and Youtube are just some of applications usually applied in online classes. Those applications have advantages as well as deficiencies respectively. Some of them require students to stay in front of their laptops or android during the class while the others give them free time to get drink while downloading the materials shared by their lecturers. WhatsApp is included to the latter one. The application released in 2009 provides the users with the ability to send messages, videos, documents, web link, voice messages, make phone calls and video calls, make groups, and others. ${ }^{6}$

All the features in WhatsApp are considered as practical and useful for conducting online classes. However, offering the easiness does not mean that this application has no deficiencies. Teaching a practice subject just like Pronunciation Practice by applying WhatsApp can be something challenging. Therefore, the researcher through this research is interested in finding out "The Using of WhatsApp in

5 EducationWorld, Impact of Online Learning on School Education (EducationWorld: retrieved from www.educationworld.in November 28 2020)

${ }^{6}$ DailySocial, Apa Itu WhatsApp, Sejarah dan Fitur-Fitur Unggulannya? (DailySocial: retrieved from https://dailysocial.id November 28 2020)
Teaching Pronunciation Practice to the Third Semester Students of Tadris English Study Program in IAIN Palu".

The researcher formulates the research question as follows, "How is the using of WhatsApp in teaching Pronunciation Practice to the third semester students of Tadris English Study Program in IAIN Palu?" The objective of this research is to find out the using of WhatsApp in teaching Pronunciation Practice to the third semester students of Tadris English Study Program in IAIN Palu. This research is expected to be: (1) A reading material for those who are interested in finding out the using of WhatsApp in teaching Pronunciation Practice; (2) A reference for English teachers and lecturers; (3) A reading material for the students of Tadris English Study Program of IAIN Palu; and (4) Future researchers who are interested in finding out the using of WhatsApp in teaching Pronunciation Practice.

\section{Literature Review}

\subsection{WhatsApp}

The growth of communication technology nowadays enables people to communicate without having credit to do a phone call. By having a smartphone and internet connectivity, a person can make a call, a video call, or just send a message through applications. One of the popular application used by many people around the world is WhatsApp.

WhatsApp Messenger or simply known as WhatsApp is free to download messenger application for smartphones. WhatsApp uses the internet to send messages, images, audio or video. ${ }^{7}$ In this

\footnotetext{
${ }^{7}$ Webwise, Explainer: What Is WhatsApp? (webwise: retrieved from https://webwise.ie November 29 2020)
} 
study, the researcher found out how the using of WhatsApp is to teach Pronunciation Practice to the third semester students of Tadris English Study Program in IAIN Palu.

\subsection{Pronunciation}

Pronunciation is one of the components of language besides grammar and vocabulary. Pronunciation undeniably becomes the first thing that a listener notices when a speaker speaks. If the pronunciation is good, the listener will definitely feels comfortable to listen to the speaker. Vice versa, if the pronunciation contains some errors, the listener will find it difficult to understand the utterances. It is not impossible that the mispronunciation will lead a listener to misunderstand the speakers' speech.

At the level of High School Education in Indonesia, pronunciation is somewhat neglected. The curriculum of English in High School focuses more to language skills, such as listening, speaking, reading, and writing. Consciously or unconsciously, those two first skills listening and speaking - rely on the good pronunciation. It is almost impossible to have good speaking without having good pronunciation. If students do not have good speaking, then how do the listeners get to understand what they speak?

\subsection{The Problem in Pronunciation} Indonesian people are heterogeneous. They come from different regions with different traditional languages. Some of Indonesian people were born by having Indonesian language as their first language, but the others do not. The latter ones acquire their local languages as their mother tongue. O'Connor states, "The main problem of English pronunciation is to build a new set of boxes corresponding to the sound of English, and to break down the arrangement of boxes which the habits of our native language have so strongly built up." 8

The existence of the first language absolutely contributes a big impact to the second language acquisition. Students who learn a second language will imitate the sentence structure and the pronunciation of the sounds of the first language to be applied in the second language learning. How much amount of the imitation done by the learner depends on how much amount the practice he does. Practice is the key to minimize the imitation. The problem then becomes more specific to the personal effort of individual to do the practice.

Having Pronunciation Practice as one of the compulsory subjects in Tadris English Study Program after completing six years of High Schools with less practice of English pronunciation becomes the starting point of the students to begin to practice and improve their English pronunciation. They begin to think that pronouncing English is difficult and that having native-speaker-like pronunciation is slightly impossible to own. This phenomenon has been discussed by linguistic researchers. The fact reveals that it is impossible to speak like a native speaker of English. The researchers draw a conclusion that the critical cut-off age for learning a language fluently is before age 10. ${ }^{9}$ Before age 10 , babies and children still have ability to imitate what they hear. They are good imitators of language. They can imitate adults' sentence structure as well as pronunciation. After age 10, the ability to imitate pronunciation decreases. This is the reason why students find it difficult to pronounce English words.

8 J. D. O'Connor, Better English Pronunciation (Cambridge: Cambridge University Press, 1998), 3.

9 BBC NEWS, Critical Window for Learning A Language (BBC NEWS: retrieved from www.bbc.com December 1 2020) 


\subsection{The Teaching of Pronunciation} Practice

Pronunciation is one of the subjects relying on practice. The more the students practice, the better their pronunciation is. However, teaching pronunciation does not merely depend on the students' action. Lecturers also take role. Kenworthy explains the seven roles of a teacher in teaching pronunciation as follows: (1) Helping learners hear; (2) Helping learners make sound; (3) Providing feedback; (4) Pointing out what's going on; (5) Establishing priorities; (6) Devising activities; (7) Assessing progress. ${ }^{10}$

Teaching pronunciation sometimes requires more energy to provide appropriate materials and becomes the model of a speaker with good pronunciation for the students. Repeating the same words can be something frustrating for lecturers of pronunciation. Minimizing the effect of the first language to the practice of English pronunciation is one of the duties of the lecturer. Students tend to pronounce English sounds that do not exist in Indonesian to the closest sounds which sounds almost the same but not exactly the same.

\section{Research Method}

This research applies a qualitative method in which the research results are not dominated by numerical data. Suharsimi Arikunto explains that a qualitative research - also known as naturalistic research - is a type of research conducted in a normal situation without manipulation and relying on the data found by the researcher himself in the field and presented in non-numerical data. ${ }^{11}$ In qualitative research, a researcher

10 Joanne Kenworthy, Teaching English Pronunciation (New York: Longman, 1988), 1.

11 Suharsimi Arikunto, Prosedur Penelitian: Suatu Pendekatan Praktik (Jakarta: Rineka Cipta, 2010), 27. does intensive interaction rather than in quantitative research. The results are presented as descriptive rather than numerical data. Bogdan and Biklen in Sugiyono state some characteristics of qualitative research as follows: (1) Qualitative researches use natural setting by relying on the researcher as the main instrument; (2) Qualitative researches are presented in descriptive method; (3) Qualitative researches focus on the process rather than products; (4) Data analysis in qualitative researches are done inductively; (5) Qualitative researches emphasize on meaning, not generalization. ${ }^{12}$

The setting of this research was at State Institute for Islamic Studies (IAIN) Palu, Jl. Diponegoro Number 23, Lere District, Western Palu, Palu, Central Sulawesi.

The participants of this research were the third semester students of Tadris English Study Program on academic year 2019/2020. The researcher taught Pronunciation Practice class for five meetings to the participants by using WhatsApp. On the sixth meeting, she distributed the questionnaire and did the interview through WhatsApp.

\section{Result and Discussion}

The participants of this research were 19 third semester students from Tadris English Study Program of Teacher Training and Tarbiyah Faculty of State Institute for Islamic Studies (IAIN) Palu. They already passed five meetings of Pronunciation Practice class by using WhatsApp. The instruments of data collection that the

${ }^{12}$ Sugiyono, Metode Penelitian Kuantitatif Kualitatif dan $R \& D$ (Bandung: Alfabeta), 13. 
researcher used were questionnaire and interview.

The researcher distributed the questionnaire sheet on November $21^{\text {st }} 2020$. The questionnaire consisted of 5 questions using Likert Scale. On the first question, the researcher asked whether the students like the class of Pronunciation Practice or not. The result showed that 7 students $(36.84 \%)$ like the class, while 12 students $(63.15 \%)$ strongly like the class. On the second question, the researcher asked them whether the class of Pronunciation Practice is important or not. The result was 3 students $(15.78 \%)$ said that it is important, while 16 students $(84.21 \%)$ said that it is really important. The third question revealed the students' opinion whether they enjoyed studying Pronunciation Practice via WhatsApp or not. The result was 12 students $(63.15 \%)$ said that it was not really enjoying, 6 students $(31.57 \%)$ said that it was enjoying, while 1 student $(5.26 \%)$ only said that it was really enjoying. The fourth question asked them whether they could understand the teaching of Pronunciation Practice via WhatsApp or not. The result was 8 students $(42.10 \%)$ could not understand it, 9 students $(47.36 \%)$ could understand it, while 2 students $(10.52 \%)$ could understand it well. The last question in questionnaire sheet asked the students whether or not they could apply all the features in WhatsApp such as voice recording, sharing documents, sharing videos and so on. The result showed that 2 students $(10.52 \%)$ could not apply it, 10 students $(52.63 \%)$ could apply it, while 7 students $(36.84 \%)$ could apply it well.

The interview sheet was distributed to the participants on the following day November $22^{\text {nd }} 2020$. The interview was conducted via WhatsApp. It consisted of 10 questions. The first questions asked about their reasons to like or dislike Pronunciation
Practice class. They stated that they like Pronunciation Practice class because it can improve their pronunciation and enables them to speak better. They can speak fluently if their pronunciation is good. The second question asked their reasons why they think that pronunciation is needed to be studied. They answered that it is needed to make their speaking understandable for their interlocutors when they speak. The third question related to their opinion about studying Pronunciation Practice via WhatsApp. Some of them think that it is not quite effective for them to practice pronunciation via WhatsApp. However, the others said that they were helped by the existence of some features in WhatsApp such as voice note, video sharing, video call, document sharing and so on to guide them to practice pronouncing English words. The fourth question asked them about the advantages in using WhatsApp for Pronunciation Practice class. Here are some advantages they explained: (1) They have more time to understand the material well since they can scroll the material up and down the screen; (2) The teaching material looks more structured and easily accessed; (3) They can learn wherever they are and whenever they can; (4) All of them have WhatsApp in their smartphone, so they do not need more space for downloading a new online teaching media; (5) Watching videos shared in WhatsApp looks like they watch videos via in-focus in classroom. The fifth question asked them about the limitation owned by WhatsApp for studying pronunciation practice. Here are the limitations they revealed: (1) They need to purchase internet data in order to stay connected to WhatsApp; (2) They cannot do video call for all of them in the class. The video call can only run for less than 10 of them; (3) They prefer to practice pronunciation directly rather than via WhatsApp. The sixth question asked the 
students about the obstacles they faced in studying Pronunciation Practice via WhatsApp. According to them, they found several obstacles as follows: (1) They needed more smartphone memory to keep files, videos, and voice recording of the teaching material; (2) Internet server sometimes was down so that they found it hard to connect to WhatsApp; and (3) They find it hard to send documents, voice recording, or videos if they run out of internet data. The seventh question asked them how they coped with the obstacles. They did the following ways to deal with the situations above; (1) They deleted unused photos, files, songs, and others to give more space for their smartphone memory; (2) They needed to find out wifi connection in order to stay connected to WhatsApp when the server was down and when they ran out of internet data. The eighth question asked them about how they understood the lecturer's explanation in teaching Pronunciation Practice via WhatsApp. They said that they could understand it by downloading and reading the documents shared, the videos shared, and the voice recording shared. If they found it hard to understand some parts in the material shared, they asked the lecturer or their friends in the WhatsApp group by writing their questions or sending their voice notes there. The ninth question asked them about their choice whether they prefer learning Pronunciation Practice via WhatsApp or direct teaching and learning in a classroom. The majority of them said that they prefer and really miss face to face class in which they can meet their friends and lecturer directly and practice pronouncing English words directly. From 19 participants, only one of them likes online class via WhatsApp, because it is more structured and easily applied. The last question in interview session asked the participants about their hopes for Pronunciation Practice class. They hope that this Covid-19 pandemic disappears and they can start face to face class of Pronunciation Practice. By learning Pronunciation Practice, they hope that their pronunciation improves as well as their speaking skill.

\section{Conclusion and Suggestions}

After analyzing the data by using questionnaire and interview, the researcher concludes that the using of WhatsApp in teaching Pronunciation Practice to the third semester students of Tadris English Study Program in IAIN Palu is practical. The students could understand the material shared via WhatsApp in the form of documents shared, videos shared, as well as voice recording shared. They could use the features in WhatsApp well such as sharing documents, voice notes, sharing videos, video call and so on in learning pronunciation practice. The students like Pronunciation Practice Class and enjoy studying it via WhatsApp. Learning Pronunciation Practice via WhatsApp has some advantages such as time flexibility as well as structured and easily accessed materials. However, it also has some limitations such as internet data availability and video call limitation. Besides, the participants faced several obstacles in learning Pronunication Practice via WhatsApp, such as the limitation of smartphone memory to save files, down internet server, and unavailability of internet data. Nevertheless, they could passed those obstacles well by deleting some unused files to give more space to the memory and finding out wifi connection to stay connected to WhatsApp when the server was down or they ran out of internet data. They could understand the teaching of Pronunciation Practice via WhatsApp by downloading and reading the documents 
shared, the videos shared, and the voice recording shared by the lecturer. When they found a difficulty, they asked their friends or the lecturer via WhatsApp group.

After completing this research, the researcher suggests several points for the improvement of teaching Pronunciation Practice via WhatsApp, as follows: (1) The teachers or lecturers can apply WhatsApp as the online media for teaching Pronunciation Practice by using the features available in WhatsApp such as document sharing, video sharing, voice notes, and video call to make the class more enjoyable; (2) The teachers and lecturers can share videos contained of songs, games or movies related to pronunciation to make the class more fun; (3) It is better for the students to participate more in the class via WhatsApp since they do not need to stand up in front of the class to share their ideas. 


\section{References}

Tim detikcom. Kapan Sebenarnya Corona

Pertama Kali Masuk RI?

(detiknews: retrieved from

news.detik.com, November 29

2020)

M. Qadri, Kasus Pertama, Satu Warga

Sulteng Dikonfirmasi Positif

Corona (detiknews: retrieved from

news.detik.com November 29 2020)

Keputusan Bersama Menteri Pendidikan dan

Kebudayaan, Menteri Agama,

Menteri Kesehatan, dan Menteri

Dalam Negeri Republik Indonesia

Nomor 03/KB/2020, Nomor 612

Tahun 2020, Nomor

HK.01.08/Menkes/502/2020,

Nomor 119/4536/SJ Tentang

Perubahan Atas Keputusan Bersama

Menteri Pendidikan dan

Kebudayaan, Menteri Agama,

Menteri Kesehatan, dan Menteri

Dalam Negeri Nomor 01/KB/2020,

Nomor 516 Tahun 2020, Nomor

HK.03.01/Menkes/363/2020,

Nomor 440-882 Tahun 2020

Tentang Panduan Penyelenggaraan

Pembelajaran Pada Tahun Ajaran 2020/2021 dan Tahun Akademik 2020/2021 di Masa Pandemi

Coronavirus Disease 2019

(COVID-19)

ANTARANEWS, IAIN Palu Kuliah Daring

Cegah Penyebaran COVID-19 (ANTARANEWS: retrieved from www.antaranews.com November 28 2020)

EducationWorld, Impact of Online Learning on School Education (EducationWorld: retrieved from www.educationworld.in November 28 2020)
DailySocial, Apa Itu WhatsApp, Sejarah dan Fitur-Fitur Unggulannya? (DailySocial: retrieved from https://dailysocial.id November 28 2020)

Arikunto, Suharsimi. Prosedur Penelitian: Suatu Pendekatan Praktik. Jakarta: Penerbit Rineka Cipta, 2010.

Sugiyono. Metode Penelitian Kuantitatif Kualitatif dan R\&D. Bandung: Alfabeta, 2008.

Webwise, Explainer: What Is WhatsApp? (webwise: retrieved from https://webwise.ie November 29 2020)

O'Connor, J. D. Better English Pronunciation, Cambridge: Cambridge University Press, 1998.

BBC NEWS, Critical Window for Learning A Language (BBC NEWS: retrieved from www.bbc.com December 12020$)$

Kenworthy, Joanne. Teaching English Pronunciation, New York: Longman, 1988. 